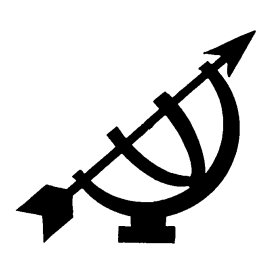

\title{
Education of quality to the poor
}

\author{
H.M. van der Merwe \\ Department of Further Teacher Education \\ University of South Africa \\ PRETORIA
}

E-mail: Vdmerhm@unisa.ac.za

\begin{abstract}
Education of quality to the poor

Quality education often eludes South African learners from poverty-stricken environments. There are, however, some notable exceptions. This article looks at how quality education based on social capital is provided to the poor. The author reports on a qualitative investigation based on both focus group and individual interviews conducted at a resource-poor KwaZuluNatal school serving learners from Grade $R$ to 9 . The findings show that quality education at the research site relates to the moral agency of the school principal and teaching staff. Through their ethics of being and doing, the school principal and teaching staff ensure that sufficient resources, sound home-school relations, and a high premium on moral values result in a receptive learner corps. This environment encourages these learners to act with diligence, honesty, politeness, respect and service to the community. The findings contribute to research that maintains that quality education is indicative of the school principal and teachers' ethics of being and of doing.
\end{abstract}

\section{Opsomming}

\section{Gehalte-onderwys aan die armes}

Gehalte-onderwys is nie vrylik beskikbaar aan leerders uit arm omgewings nie. Daar is egter merkwaardige uitsonderings. Hierdie artikel ondersoek hoe gehalte-onderwys wat op sosiale kapitaal gegrond is aan arm leerders voorsien word. Die outeur doen verslag oor 'n kwalitatiewe ondersoek gebaseer op individuele en fokusgroeponderhoude wat gevoer is by ' $n$ arm $K$ waZulu-Natalse skool vir leerders van graad $R$ tot 9 . Bevindings dui daarop dat gehalte-onderwys by hierdie navorsingsterrein verband hou met die morele bemiddeling van die skoolhoof en onderwysers. Deur middel van hulle etiek van 
wees en doen, verseker die skoolhoof en onderwysers dat voldoende hulpmiddels, gesonde verhoudings tussen die huis en skool, asook 'n hoë premie op morele waardes 'n ontvanklike leerderkorps tot gevolg het. Hierdie milieu bemagtig leerders met ywer, eerlikheid, hoflikheid, respek en bereidheid tot gemeenskapsdiens. Die bevindings dra by tot navorsing wat toon dat gehalte-onderwys 'n aanduiding is van die skoolhoof en onderwysers se etiek van wees en doen.

\section{Introduction}

Quality education is a shared aspiration due to its importance for social and economic mobility. In postapartheid South Africa the pursuit of quality education has caused an exodus from black schools and a desegregation of formerly white, Indian and coloured schools. Many black learners have come to enjoy education of quality at desegregated schools. However, the correlation between school fees and school choice has resulted in an unintentional continuance of a two-tier public schooling system: learners in black rural and township schools remain trapped in a survivalist economy, as their families are financially unable to relocate in pursuit of quality education (Pretorius, 2010:137; Soudien, 2004:106). One countermeasure has been the introduction of no-fee schools, whereby government funds the expenses previously covered by fees of schools serving resource-poor pupils (DoE, 2006:2). However, increased funding does not ensure quality education. Apart from internal factors inherent to each school, many children enter the classroom unprepared to learn. These learners need the order and ethics of effective schools that provide consistency and regularity to acquire social skills and establish work attitudes for social and economic mobility (Bloch, 2009:124; Davidoff \& Lazarus, 2002:49).

Effective schools do not have unlimited space (Hess \& Finn, 2004:13), and in South Africa where $60 \%$ of all public schools are regarded as resource-poor schools, it is crucial that the quality of education at these schools is improved (DoE, 2006:33; CREATE, 2009:3). Bloch (2009:59) emphasises that resource-poor schools in South Africa function as "sinkholes", but with some notable exceptions. The school under investigation, which has been rated "resource-poor", is a notable exception. Although its black learners are trapped in a survivalist economy, they are being equipped with social and economic mobility by virtue of the good quality education that they receive. It is argued that despite financial constraints quality education can be provided, and it is, therefore, deemed important to investigate the essence of quality education. 
Although a number of investigations have been conducted on educational provisioning to the poor (CDE, 2010; Kamper, 2008; Pollard-Durodola, 2003; Tooley, 2009), the pertinent factors responsible for quality education - regardless of financial constraints need to be continually explored to serve as comprehensive strategies for improved provisioning. In this article factors that contribute to quality education within financially-constrained environments are distinguished, so that these factors can serve as strategies for providing quality education to the poor. It is important to identify these strategies in order to continue the discourse on contextuallybound factors that contribute to education quality to the impoverished. I conducted the inquiry with social capital as the theoretical framework underlying the investigation. I examine quality education as it pertains to social capital, school effectiveness and equitable access.

\section{Social capital and quality education}

Social capital considers the individual's occupation of a certain position in a multidimensional social space that influences perceptions and behaviours. In this regard the contextual framework of Bourdieu, which is based on social dynamics theory as part of systems theory, explains social capital as the interrelated functioning between the individual and society (Bourdieu, 1984:114). The individual as social agent within a multidimensional social space is defined by numerous possible social, cultural and symbolic capital, as arranged through social networks. Society in turn, consists of various relatively autonomous fields. Each field engenders a specific complex network of social relations in terms of ethics and legitimised opinions, where individuals as social agents engage in their everyday practice. Through an inculcation of objective field structures into the subjective mental experiences of individuals, social agents develop a certain disposition for social action that is conditioned by their positioning of the field (Bourdieu, 1993:35, 86, 119).

The interspersion of the individual's positioning of the field with various social capital-related possibilities, results in the development of a certain habitus (Bourdieu, 1993:163) or moral agency (Kretzschmar, 2010:570). Habitus portrays lasting perception and behaviour that articulates in a moral agency of ethics of being and of doing (Bourdieu, 1984:170; Kretzschmar, 2010:569). Ethical preferences based on social origin represent the primary embodiment of social capital. In this regard Bourdieu (1984:406) stresses the capacity of individuals as social agents to engage their cultural produc- 
tions and symbolic systems to reproduce social structures of dominance, which for this article would relate to quality education.

Social capital, understood within the context of quality education, pertains to the contribution of parents and educators in equipping the young with the dispositions of thought and behaviour that enable them to succeed by virtue of their ethics of being and doing. In this regard social capital entails the sum of the actual and virtual resources that accrue to an individual or a group, and that converts into possessing a durable network of institutionalised relationships of mutual acquaintance and recognition (Bourdieu, 1984:63). These resources are effected by focused and effective endeavour and enterprise, conceptualised and executed by human beings (Robertson, 2010:6). It is manifested in effective schools where emotional, cognitive, spiritual, financial, and physical support structures, as well as relationship-oriented resources prevail (Kamper, 2008:1; Swift, 2003:9).

Learners from resource-poor schools are mostly the children of parents trapped in poverty (Bloch, 2009:59), and these learners' social capital resources are arranged by the teaching staff who influence learners' development positively - regardless of impeding external environmental influences (Mathibe, 2007:523; Swanepoel, 2009:464). Factors such as a lack of learning support at home, inappropriate sexual relations, family disintegration, crime and gangrelated violence, as well as peer pressure regarding substance abuse all have an impact on a child's development possibilities (Bloch, 2009:124; Pampallis, 2003:154). This results in a sustained reproduction of exclusion and marginalisation (Bourdieu, 1993:61; Swift, 2003:120). However, effective schools regarded as institutions with quality education have a positive influence on children's possibilities for economic and social mobility.

\section{School effectiveness as quality education}

School effectiveness that translates to classroom successes is mainly defined by academic outcomes in standardised tests (Blair, 2002:179). Linked to academic outcomes, learners' time, abilities and efforts are positively influenced by high education standards. When a school raises its standards, learners respond by working harder, which in turn attracts focused learners (Brunello \& Rocco, 2008:1868; Pampallis, 2003:157). Even though school outcomes are influenced by learners' social backgrounds and own abilities (Van der Werf et al., 2000:355; Orrenius, 2008:4), school environments in which the common characteristics of effective schooling prevail 
remain the most conducive to any possible learner success (Bloch, 2009:141; Pollard-Durodola, 2003:97).

Considering the strong body of literature on school effectiveness, the most common characteristics associated with effective schools which serve as indicators of quality education pertain to the following: strong leadership from the principal; a shared sense of purpose; high expectations with regard to learner achievement; sound homeschool relations; the frequent and systematic evaluation of learners; high professional standards among teachers; an orderly environment; the availability of comprehensive resources; a planned and purposeful curriculum; time on task and neat and clean buildings and facilities (Bacolod \& Tobias, 2006; Blair, 2002; Davidoff \& Lazarus, 2002; Kruger, 2003; Mathibe, 2007; Pollard-Durodola, 2003; Swanepoel, 2009; Van der Werf et al., 2000). In multi-ethnic contexts, an indicator of quality education relates to sensitivity to diversity and the creation of an environment in which learners from minority groups feel emotionally safe (Blair, 2002:190). This implies a focus on both academic needs and personal concerns, so as to raise learners' self-esteem and to reassure them of their teachers' presence as a prominent and stable aspect of their daily lives (Pollard-Durodola, 2003:110). Recognition of diversity also pertains to sensitivity to the needs of the external community and an equalising intention of pursuing the same thing for all children (Orrenius, 2008:4; Swift, 2003:41). This is linked to government's support for equitable access to education.

\section{Equitable access and quality education}

Modern society holds that all children, through education, should have a fair chance of social and economic mobility through relevant knowledge and experience that is effectively conveyed and efficiently employed (Robertson, 2010:6). Education can therefore not only be the responsibility of parents, as that would yield a pattern of unequal educational opportunities (Swift, 2003:55; Hess \& Finn, 2004:5).

In view of the right to a basic education, educational attendance is (by law) compulsory for all South African children aged seven to fifteen, or to the completion of Grade 9 (South Africa, 1996:6). Due to the considerable number of children coming from poverty-stricken families, education is made accessible by the policy of no-fee schools introduced in 2007 to the poorest $60 \%$ of South African children (DoE, 2006:31). Centred on a quintile funding system based on the rates of income, unemployment, and illiteracy within the school's 
catchment area, schools in Quintile 1 and 2 offering basic education are considered poorly resourced and thus no-fee schools (DoE, 2006:29, 33). Children at these schools access the national school nutrition programme as feeding schemes are provided at all no-fee schools.

Yet, access to education does not ensure quality education (Pampallis, 2003:161; Pretorius, 2010:137). Considering the enabling environment brought about by sufficient social capital resources (Bourdieu, 1984:63; Kamper, 2008:1), Robertson (2010:6) and Davidoff and Lazarus (2002:9) emphasise the creation of opportunities for those in impoverished circumstances to fall under the guiding hand of those who do know how to create sustainability for social and economic mobility. With regard to black learners from impoverished environments, sustainability relates to providing quality education that resides with the school principals and staff of the schools in which the poverty-stricken learners find themselves.

\section{Research design for the empirical investigation}

To understand what the main factors are that contribute to quality education, I used a qualitative intrinsic case study approach entailing individual and focus group interviewing. Concurring with Henning et al. (2004:32), I selected the qualitative case study genre for an in-depth understanding of the situation of those involved, as well as of the meaning they derived from their situation. Since my interest lay in the process rather than in outcomes, I decided that my study would entail a rich description of the context and operation of the case (Johnson \& Christensen, 2004:363) pertaining to the factors that contribute to quality education, as experienced at a school serving poverty-stricken pupils.

I conducted the investigation at a rural middle school (primary) in KwaZulu-Natal that offers basic education to learners from grade $R$ to 9. Categorised Quintile 2 on the poverty index, the school is classified as a resource-poor school. Many of the 520 learners in the school are the children of workers on sugar cane fields or of unemployed parents residing in the surrounding informal settlements. The school received a silver medal in the KwaZulu-Natal Premier's Service of Excellence Awards scheme in 2010 for excellence in good governance and service to the community. From informal communication with members of the school community it is clear that a notable number of former pupils of the school are firstgeneration higher education students, who are successful in their studies which include medicine, law and engineering. Initially es- 
tablished as an Indian school in 1928, the learner demographics of the school changed to $8 \%$ black learners by 2008 . Of the total of fifteen teachers, thirteen are Indian and two black (IS, 2008:20).

To understand the factors that contribute to quality education provided at a resource-poor school, I selected participants from different spheres of the school environment. A total of sixteen participants I regarded as most suitable to "wander with" on the research journey (Henning et al., 2004:70) provided relevant data for a deep understanding of the factors contributing to quality education at the specific school. I conducted in-depth individual interviews with the school principal, the chairperson of the school governing body (SGB), a former learner who is a first-generation higher education student (studying medicine), and a novice teacher. I also conducted three focus group interviews, which were arranged through employing the snowball sampling technique (Johnson \& Christensen, 2004:216): one with a group consisting of five teachers, one with a group consisting of four learners, and one with a group consisting of three parents. All seven interviews were guided by the same theme, namely what the main factors are that contribute to quality education at the research site. Follow-up probes related to why and how these factors represent quality education.

I used qualitative content analysis based on Tesch's model to ensure that all the perspectives and issues that arose from the data were included in the report (Poggenpoel, 1998:343). In brief, this meant that I transcribed each interview for an immersion into the data and as an initial segmentation of the data into units of meaning (De Vos, 2005:336). I followed this up with open coding by reading and re-reading each interview to ensure an overview consisting of as much contextual data as possible, so as to achieve an inductive selection of codes determined on sentence level (Henning et al., 2004:104). After axial coding I used selective coding to ensure that themes from the labelled categories were constructed and extracted to represent the interpreted and rationalised data as research findings (Henning et al., 2004:105). I referred to Guba's trustworthiness model, as explained by Poggenpoel (1998:348-350), to ensure the authenticity of my findings in terms of truth value, applicability, consistency and neutrality. I triangulated the research findings from the empirical investigation with the research findings from literature. I guaranteed the anonymity of participants and the confidentiality of their disclosures at all times during the research project.

The shortcomings of my study reside in the scope of the investigation, which was focused extensively on one school. For a more 
comprehensive interpretation of what quality education to resourcepoor pupils entails, it is suggested that further studies be conducted in which more high-poverty schools are included that provide exceptional educational opportunities to the impoverished. However, against the background of the importance of orchestrating quality education in situations in which poverty-stricken learners find themselves (Bloch, 2009:142), my investigation into the factors in quality education provided at a resource-poor school, may offer reliable evidence in directing and refining the discourse on providing quality education to pupils from impoverished backgrounds.

\section{Presentation of findings}

My empirical investigation was aimed at determining the contextually-bound aspects pertaining to quality education, as provided to impoverished learners. Several themes emerged from both the individual and focus group interviews as factors that are representative of quality education. These themes concur with factors identified in the literature as contributing to quality education. The themes related to efforts to supplement needed resources; strong leadership of the school principal; the dedication of teaching staff; the prevalence of teamwork and a sense of belonging; the high premium placed on moral values; constructive parent involvement; and service to the community. My discussion of these factors that contribute to quality education is substantiated by verbatim excerpts from the interviews. For the sake of confidentiality and authenticity, I distinguish the four learner, three parent and five teacher participants by numbers 1, 2, and so forth.

Ensuring that needed resources are available is a factor in quality education (Van der Werf et al., 2000:337). As is evident from the research site's Quintile 2 ranking, poverty prevails to such an extent that "learners are only able to concentrate fully once they have received their meal" (Novice teacher), as arranged through the feeding scheme. This meal is issued at ten o'clock in the morning and "for many this is the only meal that they do have for the day" (Principal). It is, therefore, not possible to include learners in fundraising efforts to supplement needed resources because the school has "a set of kids who are not capable of raising funds, due to their poorness they cannot; it would be unreasonable" (Teacher 1).

The ability of the school governing body to supplement resources to improve education quality is limited due to high illiteracy and poverty rates among the parent population. The result is that teachers themselves engage in efforts to acquire resources through sponsorships 
and donations. Through the mutual efforts of the teacher corps the school's infrastructure was extended with three classrooms, a sports stadium and a staff room. This occurred "all by donations and the goodness of people's hearts who just wanted to see an education happens" (Teacher 1). Donations are also pursued to broaden the learners' horizons and to improve their immediate quality of life, which serves as motivation for perseverance in the classroom. These donations are used, among others, for outings to places of interest, enjoying a meal at a restaurant, receiving a Christmas lucky packet, and having meals sponsored in addition to the daily meal served through the feeding scheme.

Strong leadership from the school principal is a factor in quality education (Blair, 2002:180). Participants agreed that the achievements of their school are the result of the school principal's strong leadership. From the findings from the individual and focus group interviews, the principal's management and technical competencies can be summarised as being fair, empowering, approachable, accommodating, transparent and compassionate - all of which encourage staff to do their best in providing quality education to the pupils. The school principal's fairness is reflected in her approach of not turning anyone away, whether he/she forms part of "her teaching staff, her support staff, the people working in the kitchen, or the cleaners" (Teacher 4). She maintains an optimal balance between a task- and people-oriented leadership approach in that "she ensures that work is done, but in a very pleasant manner" (Novice teacher). Her emphasis of time on task relates to giving direction with regard to "sticking to dates, coming to school on time, doing ground duty, be fully prepared for each lesson" (Novice teacher). This is accompanied by encouraging and empowering productivity that benefits the learners. As pointed out by the teachers:

Ma'am gives us the freedom to come up with our own ideas to benefit the children' (Teacher 3), 'but you have to go to Ma'am with a plan because she always asks "tell us how" and then she helps us' (Teacher 2).

The approachability of the school principal is reflected in her opendoor policy. Staff and parents know that they are at liberty to approach her at any time because "Ma'am always listens and always knows best" (Parent 2). Although the school principal has earned the respect of her staff, teachers admitted that "she is like one of us, she is not up there" (Novice teacher). The school principal acknowledged that she and her staff "communicate rather well" and that the teachers know that she "will not hide anything from them". Having 
their tea break together is a time of "talking and sharing" (Principal), which enables the school principal to be aware of problems and be in a position to give aid where needed in pursuit of quality education.

A dedicated teacher corps is another factor in quality education (Swanepoel, 2009:464). Learners captured the competence and compassion of their teachers as follow: "Our teachers are all so good to us" (Learner 2); "They are clever because they know everything" (Learner 4); "They do not teach us about school work only, they teach us about manners, respect" (Learner 1). Because teachers are not prepared to lower their standards, a learner stated that teachers "help us until we understand" (Learner 3). This occurs after school and should be done "because many learners need the extra help to make progress" (Teacher 1). When asked about the kind of progress that needs to be made, teachers described it as progress with regard to mastering crucial competencies such as reading fluently and grasping mathematical concepts to prepare them for secondary school and even university studies. Teachers also emphasised their approach of educating the child holistically and not focusing on teaching only. In this regard Teacher 2 pointed out that "when you see the child on the playground doing the wrong, you call the child and you sort it out; you never turn a blind eye".

With regard to their learners' battle with poverty, teachers commented that they feel compelled to give their best because "coming here every day is an opportunity to do a little bit of God's work" (Teacher 3). This they pursue even in the face of potential danger such as the situation that arose "when the teachers from other schools came for us because we chose not to strike" (Teacher 4). The result is that the children do not battle when they go to secondary school because of "the foundation that is laid very strongly, they still have the same diligence, discipline and the same respect that they learnt here" (SGB chairperson).

A shared sense of purpose is a factor in quality education (PollardDurodola, 2003:97). The words "One big happy family" (former learner), captures the gist of functioning at the research site. Teachers know each other well and they are also very well-acquainted with the circumstances of their pupils. This results in teachers "being there for each other and for the pupils" (Teacher 2). Ownership is reinforced by the principal who continuously reminds her staff that "the school is not mine, or yours, but ours" and that whatever they do, they do "for the benefit of our learners, for our school and ultimately for ourselves" (Principal). Apart from perceiving their profession as a call to provide their best for their learners, teachers 
are inspired by the receptiveness of their pupils. In this regard a teacher pointed out: "There is something about the receptiveness and appreciation of the children here, I would not swop these children for any other" (Teacher 3).

High expectations with regard to learner achievement, understood as proper behaviour, are an indicator of quality education (Swift, 2003:9). At the research site this translates into teachers putting a high premium on both practising and fostering a system of values that include diligence, respect, courtesy, honesty, and of conserving what one has. This system of values has been part of the school since its inception in 1928. The school principal explained:

We were taught that respect to value certain things, to work hard, and we are trying to teach the same thing to our learners.

This is done through a practise-what-one-preaches approach of "I respect you, you respect me" (Teacher 1); "I use my please and my thank you and you use yours" (Teacher 5). Learners' internalisation of morality is evident in their honesty because "if a child finds a hundred rand on the playground, that hundred rand will come to my office" (Principal). Based on the fact that "learners are taught to look after what they have" (Parent 3), their achievement is evident in their conserving of the school premises because "we know when a window pane breaks, it was by accident" (SGB chairperson). Learners' achievement also manifests in politeness; when hearing learners speak outside the school premises, "people assume that they are attending a model C school" (Parent 1).

Learners value the moral security prevailing at their school. This atmosphere, which allows them to be children, is sustained by the school principal and teachers who are "very clued up" and who "nip a problem in the bud" (former learner), and by the learners who "look out for each other" (Teacher 2). Parents concurred that the social capital their children are exposed to at school results in pupils learning "respect, responsibility, honesty" (Parent 3); "how to communicate" (Parent 1); "to be dedicated" (Parent 2), and "to respect the environment" (Parent 3). Learners realise that "if it was not for a school like this we would have been probably uneducated with no future" (former learner). When asked what is meant by "a school like this", the participant explained that it relates to provisioning that is on par with the order, ethics and learning achievements experienced in effective schools and that serve as indicators of quality education. 
Sound home-school relations are an indicator of quality education (Van der Werf et al., 2000:354). Although the majority of parents at the research site are very poor and illiterate, constructive parent involvement is maintained in that parents' position as primary educators of morality is acknowledged and called upon. Sound parent-school relationships prevail because "parents know that I will not call them unless I have done an investigation and am trying to correct behaviour" (Principal). For that reason parents come to school when asked, "or we phone them if we can and speak to them over the phone" (Principal). Teachers concurred that although the parent corps is "not literate" (Teacher 1), they get "parents' moral support" (Teacher 2) because parents always admit that "what my child did was wrong" (Teacher 4). Parent participants interpreted their children's quality education as manifesting in "happy and disciplined children" (Parent 1) who understand that "there are other people out there who also matter and who also have to be respected" (SGB chairperson). Parents concurred that the fact that they "can approach the school anytime" (Parent 2) contributes to sound home-school relationships with a positive influence on their children's learning.

A school that is focused on the needs of the external community is an indicator of quality education (Van der Werf et al., 2000:338). In this regard the school under investigation is "a community-based school that cares for the community holistically" (SGB chairperson). The school principal and staff consider their profession as one of "not just being teaching in the school, but also caring for the needy community" (Principal). Many projects are undertaken to assist community members in crises, for example: "collecting food and clothes for the family whose house recently burnt down" (Novice teacher); collecting money among themselves "for the bus ticket of an ex-pupil" (Teacher 2) for whom transport to complete her matric became a problem when her father had a massive stroke; transport money "for a pupil's mother who needed to go for chemotherapy" (Teacher 5).

Learners are encouraged to participate in community care projects, because however poor they are and however small their contributions, the value should be fostered that "it is not always for take, you have to consider the next person" (Teacher 1 ). With regard to compassion to strengthen home-school and school-community relations, teachers "walk into all kinds of shacks and all kinds of homes" (Teacher 1) to show their empathy when there is illness or death in the family. The school principal emphasised that support to the 
community is maintained even after the learner has completed Grade 9 because "it is not like once you have gone from here it is over". For that reason, loyalty to the school and service to the community are nurtured in that learners are taught "when you go (after completing Grade 9), make sure you come back and when you come back, if you can help, you help" (SGB chairperson).

\section{Discussion}

The large numbers of poor learners in South Africa, and the fact that a basic education is compulsory and important for social and economic mobility, demand that the schools where the poor learners find themselves are improved to correspond with the factors that contribute to quality education (Bloch, 2009:142). The lack of quality education in poor schools pertains to varied learning contexts that relate to varied social capital (Pampallis, 2003:154; Pretorius, 2010: 120). Quality education, understood as the provisioning of comprehensive social capital resources, assists pupils emotionally, cognitively, spiritually and physically to develop a disposition for social and economic mobility, based on preparedness for a specific position in a multidimensional social space (Bourdieu, 1993:35; Kamper, 2008:1). Essential to the presence of social capital as quality education are school principals with their teaching staff who act as social agents, informed by a specific moral agency that translates into an ethics of being and doing, and which determines the type of education provided to pupils (Kretzschmar, 2010:569; Swanepoel, 2009:464).

Education of quality is provided to impoverished pupils at the school at which the research was done. This school is rated as a resourcepoor school. Factors that contribute to quality education, triangulated by literature findings, were found to pertain to strong leadership by the school principal who - with teamwork and a shared sense of purpose among a dedicated teaching staff - ensures that needed resources and sound home-school relations translate into proper learner behaviour and notable learner achievement. Sufficient resources obtained through sponsorships contribute to an improvement of the physical teaching and learning environment and the improvement of learners' quality of personal life. The school principal and her staff are sensitive to learners' background. This approach, together with additional assistance to learners from resource-poor family environments, ensures that high academic standards are maintained in terms of being prepared for secondary school and eventually for possible higher education studies. 
The high premium placed on moral values, expressed by practising respect, honesty and diligence, results in an enabling opportunity for social and economic mobility due to the benefits of holistic preparedness that is based on knowledge, skills and behaviour. In line with the findings of Davidoff and Lazarus (2002:53), this holistic preparedness enables learners to be truly human. Their humanity manifests in communicating politely, rendering their assistance willingly, and considering human dignity. All of these virtues contribute to an orderly environment that is conducive to learning. Although most of the parents are illiterate, the principal and staff have succeeded in constructively involving them. Consequently, the parents provide valuable moral support. This not only empowers parents as primary educators, but it also enhances proper pupil behaviour for optimal learning. The experience of a shared sense of purpose, as articulated in the conservation of the school environment, is extended to loyalty and service to the needy community. Learners' engagement in community service projects results in a nurturing of altruism, which not only fosters an awareness of symbiotic existence, but alerts pupils to their individual responsibility for comprehensive societal sustainment.

In view of the main factors inherent to effective schools, as described in the literature, it is evident that the education provided at the resource-poor school under investigation exhibits the factors essential to quality education. The school provides quality education to impoverished learners, where they are, thus enabling them to develop further than what would have been expected - considering the limited social capital resources to which they are exposed in their home environments.

\section{Conclusion}

In line with the findings of Bourdieu (1984:406) on the importance of social capital to equip the young with the dispositions of thought and behaviour that enable them to succeed by virtue of their ethics of being and doing, the habitus of educational provisioning at the research site represents quality education. Strategies for quality education relate to ensuring that learners are exposed to enriching events; that learners are exposed to high moral values; that learners are ensured of their teachers' presence as a prominent and stable aspect of their daily lives; that with sensitivity for diversity learners are enabled to master knowledge and skills to prepare them for social and economic mobility; and that an awareness for societal responsibility is nurtured. The moral agency of the school principal 
and teaching staff is essential for the application of these strategies. The ethics of being and doing of a school's teaching staff should equip learners with diligence, honesty, politeness and respect for human and environmental dignity to capacitate learners for success in secondary school and possibly future higher education studies.

Considered comprehensively, the education of quality to which learners at a resource-poor school is exposed should equip them with the dispositions of thought and behaviour to define their expectations about life beyond the school. To determine the rippling effect of enabling possibilities that result from the school staff's moral agency, further studies can focus on determining the scope of ethics of being and doing of young adults who came from resource-poor families, and who were exposed to quality education at notable resource-poor schools.

\section{List of references}

BACOLOD, M.P. \& TOBIAS, J.L. 2006. Schools, school quality and achievement growth: evidence from the Philippines. Economics of education review, 25:619-632.

BLAIR, M. 2002. Effective school leadership: the multi-ethnic context. British journal of sociology of education, 23(2):179-191.

BLOCH, G. 2009. The toxic mix: what's wrong with South Africa's schools and how to fix it. Cape Town: Tafelberg.

BOURDIEU, P. 1984. Distinction: a social critique of the judgement of taste. London: Routledge.

BOURDIEU, P. 1993. The field of cultural production: essays on art and literature. New York: Columbia University Press.

BRUNELLO, G. \& ROCCO, L. 2008. Educational standards in private and CDE public schools. The Economic journal, 118:1866-1887, Nov.

see CENTRE FOR DEVELOPMENT AND ENTERPRISE

CENTRE FOR DEVELOPMENT AND ENTERPRISE. 2010. Hidden assets: South Africa's low-fee private schools. http://www.cde.org.za Date of access: 22 Oct. 2010.

CONSORTIUM FOR RESEARCH ON EDUCATION, ACCESS, TRANSITIONS \& EQUITY. 2009. No-fee schools in South Africa: policy brief, number 7, August. http://www.CREATE-rpc.org Date of access: 30 Mar. 2011.

CREATE see CONSORTIUM FOR RESEARCH ON EDUCATION, ACCESS, TRANSITIONS \& EQUITY

DAVIDOFF, S. \& LAZARUS, S. 2002. The learning school: an organisation development approach. Cape Town: Juta.

DE VOS, A.S. 2005. Qualitative data analysis and interpretation. (In De Vos, A.S., ed. Research at grass roots: for the social sciences and human service professions. Pretoria: Van Schaik. p. 333-349.)

DEPARTMENT OF EDUCATION. 2006. National norms and standards for school funding. Government gazette, 494(29179). 


\section{DoE}

see DEPARTMENT OF EDUCATION

HENNING, E., VAN RENSBURG, W. \& SMIT, B. 2004. Finding your way in qualitative research. Pretoria: Van Schaik.

HESS, F.M. \& FINN, C.E. 2004. Leaving no child behind? Options for kids in failing schools. New York: Macmillan.

IS

SEe ISNEMBE SCHOOL

ISNEMBE SCHOOL. 2008. Commemorative brochure, 1928-2008. Tongaat: Isnembe school.

JOHNSON, B. \& CHRISTENSEN, L. 2004. Educational research: quantitative, qualitative, and mixed approaches. Boston: Pearson.

KAMPER, G. 2008. A profile of effective leadership in some South African highpoverty schools. South African journal of education, 28(1):1-18.

KRETZSCHMAR, L. 2010. Cultural pathways and pitfalls in South Africa: a reflection on moral agency and leadership from a Christian perspective. Koers, 75(3):567-588.

KRUGER, A.G. 2003. Cultivating a culture of learning and teaching. (In Van Deventer, I. \& Kruger, A.G., eds. An educator's guide to school management skills. Pretoria: Van Schaik. p. 245-254.)

MATHIBE, I. 2007. The professional development of school principals. South African journal of education, 27(3):523-540.

ORRENIUS, P.M. 2008. Immigrant assimilation: is the US still a melting pot? Federal Reserve Bank of Dallas. http://www.dallasfed.org/research/ indepth/2004/id0401a.html Date of access: 18 Sept. 2008.

PAMPALLIS, J. 2003. Education reform and school choice in South Africa. (In Plank, D.N. \& Sykes, G., eds. Choosing choice: school choice in international perspective. New York: Teachers College Press. p. 143-163.)

POGGENPOEL, M. 1998. Data analysis in qualitative research. (In De Vos, A.S., ed. Research at grass roots: a primer for the caring professions. Pretoria: Van Schaik. p. 334-353.)

POLLARD-DURODOLA, S. 2003. Wesley Elementary: a beacon of hope for atrisk students. Education and urban society, 36(1):94-117.

PRETORIUS, S.G. 2010. The South African education system. (In Lemmer, E. \& Van Wyk, N., eds. Themes in South African Education. Cape Town: Heinemann. p. 117-140.)

ROBERTSON, J. 2010. The essence of sustainable wealth creation. Civil engineering, 18(6):6-8.

SOUDIEN, C. 2004. "Constituting the class": an analysis of the process of "integration" in South African schools. (In Nkomo, M., McKinney, C. \& Chisholm, L., eds. Changing class: education and social change in postapartheid South Africa. Pretoria: HSRC. p. 89-114.)

SOUTH AFRICA. 1996. South African Schools Act, Act no 84 of 1996. Cape Town: Office of the President.

SWANEPOEL, C. 2009. A comparison between the views of teachers in South Africa and six other countries on involvement in school change. South African journal of education, 29(4):461-474.

SWIFT, A. 2003. How not to be a hypocrite: school choice for the morally perplexed parent. London: Routledge.

TOOLEY, J. 2009. The beautiful tree: a personal journey into how the world's poorest people are educating themselves. Washington: CATO Institute. 
VAN DER WERF, G., CREEMERS, B., DE JONG, R. \& KLAVER, E. 2000. Evaluation of school improvement through an educational effectiveness model: the case of Indonesia's PEQIP Project. Comparative education review, 44(3):329-355.

\section{Key concepts:}

education provisioning to the poor moral agency quality education social capital

\section{Kernbegrippe:}

gehalte-onderwys morele bemiddeling onderwysvoorsiening aan die armes sosiale kapitaal 
